\title{
Reverse Transfers of Innovation and National Development: Evidence from Brazilian Subsidiaries
}

\author{
Maitê Alves Bezerra ${ }^{1 *}$, Felipe Mendes Borini ${ }^{2}$, Maria Laura Ferranty Maclennan ${ }^{3}$
}

\begin{abstract}
The search for innovation has become an important motivation for the internationalization of companies in emerging countries. In that context, this study tests the impact that a nation's development has on whether subsidiaries transfer innovation of products or that of processes. Survey data collected from 73 subsidiaries of Brazilian companies indicate that companies located in developed markets tend to transfer more product-oriented innovations than do those based in emerging countries. Furthermore, the size and age of a subsidiary has an impact on the transfer process. The larger and younger the subsidiary, the more likely a company is to favor the flow of product innovation into its headquarters. The level of national development was not identified as an influence on the flow of process innovation.
\end{abstract}

Keywords: reverse transfer, innovation transfer, product innovation, process innovation, subsidiaries

Submitted: July 17th 2015 / Approved: December 4th 2015

\section{Introduction}

Multinational corporations in developing countries (DMNCs) have been prominent in both the international business (Verbeke \& Kano, 2015) and the innovation process literature (Fleury et al., 2013). The search for technological knowledge has become part of DMNCs' internationalization strategies (Alvaro et al., 2015).

Technological knowledge developed by subsidiaries in advanced countries has been imported by DMNCs' headquarters (Iammarino et al., 2008). At the same time, emerging countries have developed in-house innovation by offering new applications of imported technologies at much lower costs (Prahalad \& Mashelkar, 2010), the study of innovation in emerging multinational companies has become an important research topic. Unlike companies in developed countries that are already in advanced stages of industrialization, most DMNCs still must enhance their innovation capabilities. Some authors argue that DMNCs' strategic models are guided by the search for overseas resources, such as technological knowledge, that can be combined with its existing resources (Bartlett \& Ghoshal, 2000). For DMNCs, skills acquired in the international market are of obvious importance. Thus, we seek to understand the type of technological knowledge that is transferred from subsidiaries to headquarters located in emerging markets (i.e., reverse transfers of knowledge) and whether transferred knowledge varies depending on the type of environment at the subsidiary's location.

Two theoretical approaches arising out of the innovation literature are used in this study: the innovation systems (IS) approach and the emerging-markets innovations approach. The IS literature shows how developed countries' institutional environments stimulate a company's ability to innovate when developing new products (Edquist,
2005; Nelson, 1993). Product innovation is defined as a new technology or a combination of existing high-level technologies, which are sometimes disruptive and involve a high degree of investment and uncertainty (Ariffin \& Figueiredo, 2004). The literature on innovation in emerging markets explains how less-developed institutional environments induce companies to overcome their restrictions (Govindarajan \& Trimble, 2012; Immelt et al., 2009). Ramamurti (2008) argues that the specific advantages of DMNCs are closely related to process innovation, defined as the skills used in a production system, because DMNCs have superior productive efficiency. They create a capacity to produce at low costs with few resources and a low level of technology, but with an abundant labor force. Thus, the emergence of innovations in emerging markets challenges the IS view because the process of innovation can arise in developing countries where there exist no sophisticated institutional environments that would promote it (Govindarajan \& Ramamurti, 2011).

In this way, the literature indicates that DMNCs seek different types of innovation abroad. On the one hand, when subsidiaries of DMNCs are installed in developed markets, they search for product innovations. On the other hand, when DMNC subsidiaries are installed in emerging countries, they search for process innovations. These assumptions led to the formulation of our research question: Compared to DMNC subsidiaries based in developed countries, do DMNC subsidiaries based in emerging markets transfer a different type of innovation to company headquarters? To answer that question, this study uses the results of a 2013 survey of DMNC subsidiaries.

This paper aims to demonstrate that subsidiaries located in emerging markets are more likely to transfer innovations in processes compared to subsidiaries located in developed countries, which tend to transfer innovations in products. Although there are studies that propose and

1 Department of International Business and Strategy, Henley Business School - University of Reading Whiteknights, Reading, Berkshire, United Kingdom 2 Department of International Business Studies, Escola Superior de Propaganda e Marketing (ESPM-SP) São Paulo, Brazil.

3 Department of Business Studies, University of São Paulo, Brazil

${ }^{*}$ Corresponding author: m.alvesbezerra@pgr.reading.ac.uk 
investigate knowledge transfer from DMNC subsidiaries to company headquarters (Mudambi et al., 2014) none of them explain the type of transferred innovation (i.e., process- or product-oriented) to which they refer. Moreover, the results we seek deepen the knowledge of innovations in DMNCs because, according to Ramamurti (2008, p. 10), "It took many years of research to identify and empirically confirm the firm-specific advantages (FSAs) of Western MNEs, and an equally diligent effort is necessary to uncover the FSAs of EMNEs."

The ideas presented in this study can help managers to better understand the pattern of DMNCs' innovation and knowledge transfer and to facilitate the identification of the best strategies for acquiring knowledge abroad. Governments, as an integral part of both the innovation process and knowledge development, can also benefit from our findings (Edquist, 2005). It is important to understand the pattern of innovation transfer from sites with different levels of development so that governments can support companies with policies that are both appropriate and coherent.

\section{Theoretical Background}

The literature traditionally assumes that innovation and technical development originate in companies located in developed countries (Utterback, 1996). However, studies have suggested that innovation can also occur in developing countries (Govindarajan \& Ramamurti, 2011; Hobday, 2005). The literature on innovation uses two approaches. First, the IS approach focuses on developing innovations in developed countries (Lundvall et al., 2002). The second approach focuses on innovation studies of emerging markets (Govindarajan \& Trimble, 2012; Immelt et al., 2009; Ramamurti, 2008). These two research lines converge on the idea that the level of development of the environment in which a company is based affects its ability to innovate. Nevertheless, we pause to explain how this process unfolds.

\subsection{Innovation Systems}

On the one hand, for Schumpeter (1928, p. 378), innovation means proposing new uses or new combinations of factors. Nelson (1993) interprets the concept of innovation as the implementation of new products or processes. Although the OECD's Oslo Manual (OECD, 1997) has defined innovation as a broader concept, in this study innovation is split into two types: innovations in products and innovations in production processes. Product innovation comprises new technologies or technological combinations comersialised in order to meet consumer needs. On the other hand, process innovations are characterized by new uses of workforces, information and flows, task specifications, and material inputs for production (Bell \& Pavitt, 1995; Utterback \& Abernathy, 1975).

According to Nelson (1993), the innovation process of a firm is influenced by political and organizational considerations. Freeman (1995) states that successful innovation depends not only on research and development $(\mathrm{R} \& \mathrm{D})$ but also on a wide variety of other environmental factors, such as education and science-technology systems. IS compris- es organizations and institutions influencing the development, spread, and use of innovations (Lundvall et al., 2002; Nelson, 2006).

Freeman (1995) argues that low innovation levels can be explained by factors such as inefficient educational systems for training engineers, low investment in R\&D, low levels of scientific production and technology transfer, and weak relationships with industry. In line with this argument, Nelson (1993) concludes that factors such as quality education and pro-innovation policies can stimulate environments with high innovative performance. Thus, developed IS lead to enterprises with increased innovation capacity.

In recent years, the literature on the IS concept has shown accelerated progress, and its studies have primarily been conducted in the context of developed countries (Lundvall et al., 2002). Innovation in developed countries tends to meet the sophisticated needs of high-income consumers (Vernon-Wortzel \& Wortzel, 1988). Because developed countries have more developed IS with high levels of investment in R\&D and basic science, the qualification of their workforces, good incentives to innovate, and well-structured science and technology sectors, their companies are more likely to engage in product-oriented innovation. Product innovation tends to be driven by new market needs. Therefore, it is expected that companies with high levels of product innovation rely heavily on external sources of information. Moreover, this type of innovation demands a high level of investment because there is a great deal of uncertainty about market acceptance of new products (Utterback, 1996; Utterback \& Abernathy, 1975).

Thus, companies located in developed countries have access to advanced, cutting-edge technologies conceived in environments with solid IS. Such technologies are not available in developing countries due to those countries' institutional deficiencies. Thus, it is expected that by installing subsidiaries in developed countries, DMNCs seek product innovations that are not available in their home countries. These technologies, when combined with innovative, primarily process-oriented capabilities already developed by DMNCs in their countries of origin, lead such companies to build their competitive advantages. Thus, the following hypothesis is established:

\section{H1: DMNC subsidiaries located in developed countries tend to transfer product innovations to their headquarters.}

\subsection{Innovation in Emerging Markets}

Hobday (2005) presents a critical analysis of the innovation models that have been developed in the context of developed countries. According to that author, innovation theories fail to address the challenges faced by companies that have not reached the technological frontier. Most of the models consider only centralized R\&D activities, both failing to recognize the diversity and unpredictability of the innovation process and failing to present empirical evidence. Another criticism, proposed by Figueiredo (2009), addresses the traditional metrics for measuring innovation. According to that author, innovations in emerging markets are based on small improvements in existing 
processes. This fact is explained by DMNCs' lack of innovative capacity and leads to a low incidence of R\&D departments and a low level of patenting activities. Thus, the number of registered patents and the amount of investment in R\&D are both inappropriate metrics for assessing the level of DMNCs' innovation (Figueiredo, 2009).

Companies in emerging markets engage in considerably less product innovation than do companies in developed markets because companies in emerging markets lack high technology (Vernon-Wortzel \& Wortzel, 1988). The combination of cost constraints and market opportunities is the key driver of innovation for companies in developing countries. This is because DMNCs create processes that allow them to produce at very low costs while making their goods available to large numbers of consumers (Prahalad \& Hart, 2002; Prahalad \& Mashelkar, 2010). These companies import technology from advanced economies (Kim, 1997) and create business models that offer low costs initially and higher quality later. By offering quality at low costs, such companies change the business models in their sectors (Govindarajan \& Ramamurti, 2011; Govindarajan \& Trimble, 2012; Prahalad \& Hart, 2002). They are learning to "learning to do more with less for more people” (Prahalad \& Mashelkar, 2010, p. 134).

Serving low- and middle-income consumers requires the development of new business models (Prahalad \& Hart, 2002). Thus, the competitive advantage of DMNCs is based not on cutting-edge technologies, but instead on disruptive business models (Govindarajan \& Ramamurti, 2011; Prahalad \& Mashelkar, 2010). Because DMNCs do not have enough infrastructure to develop new products, they build uniquely innovative environments based on continuous improvements in their industrial processes (Prahalad \& Mashelkar, 2010).

Thus, there is evidence that DMNCs that have installed subsidiaries in emerging countries are looking not for cutting-edge technologies and product innovations, but instead for new, disruptive business models. Some emerging countries have developed extraordinary methods of structuring production processes based on the constraints of their institutional environments. Such restrictions can be similar to the constraints of the environments where DMNCs' headquarters are located. Thus, the process innovations of other emerging countries can be extremely useful in building a DMNC's technological capabilities, primarily to compensate for institutional shortcomings that still challenge headquarter in its country of origin. Based on this observation, the second hypothesis of this article is established:

$\mathrm{H} 2$ : Subsidiaries of DMNCs located in emerging countries tend to transfer innovations in production processes to their headquarters.

\section{Methods}

The overall objective of this research is to examine whether there are differences in the types of innovation transferred from subsidiaries of Brazilian companies as a function of the countries in which they are hosted. To this end, a survey was conducted to investigate the flow of technology transferred from the subsidiaries to the headquarters of Brazilian companies. However, because the official number of Bra- zilian companies with manufacturing operations abroad is unknown, we sampled 63 Brazilian multinational companies in the industrial, commercial, and service sectors, all of which had foreign production units and R\&D centers. These companies were identified through secondary sources such as the GINEBRA Project (Gestão Empresarial para Internacionalização das Empresas Brasileiras-Management Systems for the Internationalization of Brazilian Enterprises), an annual survey of the Fundação Dom Cabral (Dom Cabral Foundation), Valor Econômico (The Economic Value), and SOBEET surveys and data from the Observatório de Multinacionais Brasileiras (Center of Brazilian Multinationals) of the ESPM (Superior School of Advertising and Marketing).

From the 63 listed headquarters, we were able to identify 240 subsidiaries with manufacturing operations and R\&D centers. Seventyeight of those subsidiaries agreed to answer the survey. The data collection consisted of a questionnaire with closed questions (a 5-point Likert scale). A pretest was conducted to identify potential problems with the questionnaire. The paper questionnaire was used in the pretest, which was evaluated by three researchers in the field and three professionals in engineering and product development (Cooper \& Schindler, 2006). In this step, adjustments were made in the questionnaire to improve the respondents' understanding.

After the pretest, data collection was performed by an electronic survey (Wright $\&$ Schwager, 2008). The research resulted in a total of 78 responses, totaling a rate of return of $32.5 \%$ of the subsidiaries initially identified. However, due to the existence of missing values and outliers for the variables used in the proposed research, the present study ultimately analyzed only 73 Brazilian subsidiaries.

\subsection{Building the research variables}

The data used in this study, including both the dependent variables (the reverse transfer of process and product innovation) and the independent variables (size, age, and mode of entry), originated from the survey. Furthermore, secondary data were used (independent variable: "classification of the country as developed or undeveloped").

The dependent variable was the reverse transfer of process innovation. This construct was developed from the research by Iammarino et al. (2008). The type of innovation flow was classified as product innovation or process innovation. The construct of each type of innovation identified the presence of reverse transfer of: (1) new processes/ products; (2) significant improvements in processes/products; or (3) the adaptation of processes/products. The construct of flow of process innovation (Iammarino et al., 2008), consisting of three items, used the Cronbach's alpha of $\alpha=0.868$. The second dependent variable, the reverse transfer of product innovation (Grossman \& Helpman, 1991; Utterback \& Abernathy, 1975), consisted of three items $(\alpha=0.842)$.

The independent variable was the country where the subsidiary is located. This is because local development is an important determinant of the development of a subsidiary's capacities (Benito et al., 2003). Because this study examines the flows of innovation transfer to head- 
quarters from subsidiaries located in both developed and emerging markets, countries were divided into the two dimensions of developed and emerging markets. To this end, the classification given by the In-

Table 1: Classification of countries by level of development

\begin{tabular}{|c|c|c|}
\hline Country & Subsidiaries & Classification \\
\hline Angola & 1 & Emerging \\
\hline Argentina & 13 & Emerging \\
\hline Bolivia & 2 & Emerging \\
\hline Chile & 5 & Emerging \\
\hline China & 5 & Emerging \\
\hline Colombia & 7 & Emerging \\
\hline France & 2 & Developed \\
\hline Germany & 1 & Developed \\
\hline Hong Kong & 1 & Developed \\
\hline India & 1 & Emerging \\
\hline Italy & 1 & Developed \\
\hline Japan & 2 & Developed \\
\hline Libya & 1 & Emerging \\
\hline Mexico & 7 & Emerging \\
\hline Netherlands & 2 & Developed \\
\hline Peru & 1 & Emerging \\
\hline Portugal & 1 & Developed \\
\hline Slovakia & 1 & Developed \\
\hline Spain & 1 & Developed \\
\hline Turkey & 1 & Emerging \\
\hline UAE & 1 & Emerging \\
\hline Uruguay & 3 & Emerging \\
\hline USA & 11 & Developed \\
\hline Venezuela & 2 & Emerging \\
\hline
\end{tabular}

Source: IMF (2010)

ternational Monetary Fund was used (IMF, 2010), as shown in Table 1. From this classification, the variable was transformed into a dummy variable ( 0 for developed country, and 1 for emerging country).

Some variables were controlled: foreign entry mode (Greenfield or acquisition), subsidiary age, and enterprise size (measured by number of employees).

The first control variable was the mode of entry abroad. The choice of entry mode into international markets can affect the decision to place an innovation center in the subsidiary. Some authors argue that the search for innovations can be accelerated if a subsidiary is stablished through acquisition (Meyer et al., 2009). In the case of an acquisition, it is possible that the acquired company would already have its own R\&D center (Cantwell \& Mudambi, 2005), which would favor innovation development in a decentralized manner. Thus, the entry mode variable used in this study was obtained from the survey and was a dummy in which 0 was Greenfield and 1 was acquired.

The age of the subsidiary was also used as control variable. This was also taken from the survey results and represented the difference between the year of a subsidiary's establishment and the year that the primary data collection was completed (2013). New subsidiaries are strongly dependent on company headquarters when making decisions (Dunning \& Lundan, 2008), which can slow the development of local innovations (Cantwell \& Mudambi, 2005).

Finally, the size of the unit can influence the development of innovation in subsidiaries. This is because branch size affects a subsidiary's autonomy and its ability to acquire tangible and intangible assets abroad (Johnston \& Menguc, 2007). Larger subsidiaries have a greater ability to exploit economies of scale in $\mathrm{R} \& \mathrm{D}$ and diversify risks in their innovation portfolios (Kottaridi et al., 2008). The number of employees was taken as an indication of the size of the international unit and was computed from the survey responses.

\section{Results}

To analyze the 73 subsidiaries represented in the sample, descriptive statistics were initially used. Data analysis indicates that $32 \%$ of surveyed subsidiaries are located in developed countries and $68 \%$ in emerging markets (see Table 1).

With respect to control, it is observed that $78 \%$ of companies entered through acquisitions and $22 \%$ by Greenfield. The firms' average age was approximately 10 years, with a median of 6 years. In terms of size, only $25 \%$ of the sampled companies had more than 600 employees. In turn, $50 \%$ of the total sample had between 100 and 600 employees. Because the main objective of the research is to examine whether there are differences in the transfer of product and process innovations, it is important to note that on a 1-5 scale, the mean for process innovation is 2.45 and the mean for product innovation is 2.51 . In other words, the two types of innovation are not disparate, which shows that the reverse transfer of innovation is still modest.

Table 2 shows the correlations of the variables in this study. Independent variables do not have significant correlation, which eliminates the possibility of multicollinearity, with exception of age and size, which are significantly correlated. Therefore, the two variables will be used together in the regression model only if they do not present a VIF higher than 5 (Hair Jr et al., 2009). In turn, among the dependent variables there is a median and significant correlation, which indicates that an exploratory factor analysis should be carried out to verify whether the two proposed constructs truly reflect the two components (factors). The factorial is presented below: 
Table 2: Correlations

\begin{tabular}{lcccccc}
\hline process & 1 & 2 & 3 & 4 & 5 & 6 \\
2 product & $.576^{* *}$ & 1 & & & & \\
3 country & .132 & $.443^{* *}$ & 1 & & & \\
4 size & .066 & .092 & .180 & 1 & & \\
5 acquisition & -.154 & .038 & .145 & .052 & 1 & \\
6 age & -.084 & -.135 & .150 & $.715^{* *}$ & .000 & 1 \\
\hline \hline
\end{tabular}

Note. ${ }^{* *} \mathrm{p}<0.01$

Source: authors

Exploratory factor analysis was performed with the six variables of innovation that make up the two constructs. The results show a $0.793 \mathrm{KMO}$ and a significant sphericity test $(\mathrm{P}<0.01)$. In Table 3 , the anti-image headquarters shows that the values of MSA (main diagonal) are high and are not inferior to the other off-diagonal values, again meeting the requirements for applying the technique.

Table 3: Anti-Image Matrix

\begin{tabular}{llrrrrrr|c} 
& & 1 & 2 & 3 & 4 & 5 & 6 & Commonalities \\
2 & Development of new processes & $.857^{\mathrm{a}}$ & & & & & & .734 \\
3 & Small changes in the process & -.228 & $.791^{\mathrm{a}}$ & & & & & .800 \\
4 & Significant improvements in the processes & -.373 & -.503 & $.799^{\mathrm{a}}$ & & & & .844 \\
$\mathrm{D}$ & Small adjustments in products & .078 & -.269 & -.053 & $.796^{\mathrm{a}}$ & & & .724 \\
& Significant improvements over existing & -.257 & .160 & -.071 & -.577 & $.725^{\mathrm{a}}$ & & .850 \\
& products & & & & & & & \\
\hline \hline
\end{tabular}

Source: authors

Moreover, it is found that all of the commonalities are above 0.700 and, therefore, are appropriate (Maroco, 2010).

The method for obtaining factors was the principal component analysis with varimax rotation. The analysis resulted in a factor (eigenvalue greater than one) with a percentage of explained variance of $79 \%$, where Factor 1 explains $42 \%$ of the variance, and Factor 2 explains $37 \%$. This shows that both of the retained factors have very closely weighted values for explained variance. Table 4 presents the weights of the retained factors.

Table 4: Retained Components

\begin{tabular}{lcc} 
& \multicolumn{3}{c}{ Component } \\
Significant imp rovement in process & 1 & 2 \\
Small changes in the process & $\mathbf{. 8 9 6}$ & .203 \\
Development of new processes & $\mathbf{. 8 6 7}$ & .222 \\
Development of new products &. $\mathbf{7 9 6}$ & .318 \\
Significant improvement in products & .096 & $\mathbf{. 8 7 0}$ \\
Small adjustments in products & .336 & $\mathbf{. 8 5 9}$ \\
\hline \hline Source: authors & .441 & $\mathbf{. 7 2 7}$ \\
\hline
\end{tabular}

It is noted that Factor 1 corresponds to the innovation process construct, as previously idealized. Likewise, Factor 2 corresponds to the product innovation construct. Therefore, the constructs of process and product innovation represent two different facets of innovation that will be tested for reverse transfer by regression tests as follows.
The regression model is presented in Table 5. Multicollinearity among variables was measured by the VIF test. Because the test results show values lower than 5, no multicollinearity is found for this analysis (Hair Jr et al., 2009). Models 1 and 3 show only the control variables, for product and process innovation, respectively, whereas Models 2 and 4 include the central independent variable, which is the location of the subsidiary in developed and undeveloped countries. 
Table 5. Regression Models

\begin{tabular}{l|cc|cc|c} 
& \multicolumn{2}{|c|}{ Process Innovation } & \multicolumn{2}{c|}{ Product Innovation } & \\
Codel 1 & Model 2 & Model 3 & Model 4 & VIF \\
Constant & 3.063 & 3.005 & 2.864 & 2.676 & \\
Size (employees) & .001 & .002 & $.002 *$ & $.002 *$ & 2.081 \\
Acquisition & -.476 & -.526 & .006 & -.153 & 1.027 \\
Years at host country & -.027 & -.028 & $-.041 *$ & $-.043 * *$ & 2.059 \\
Host Country & $-\mathrm{x}-$ & .331 & $-\mathrm{x}-$ & $1.067 * *$ & 1.052 \\
\hline $\mathrm{F}$ & 1.813 & 1.798 & 2.346 & $6.673 * *$ & \\
$\mathrm{R} 2$ adjusted & 0.036 & 0.044 & 0.055 & 0.245 & \\
$* \mathrm{p}<0.05 * * \mathrm{p}<0.01$ & & & & \\
\hline \hline Source: authors & \multicolumn{7}{l}{}
\end{tabular}

The results show that Models 1 and 3, without the independent variable, have no statistical significance $(F>0: 05)$. Including the independent variable, we observe that the variables of Model 2 cannot explain the reverse transfer of this type of innovation. In the other hand, Model 4, with $\mathrm{R}^{2}$ of $24 \%$, shows that, as expected, there is an association between product innovation and a subsidiary's location in a developed country. In addition, product innovation appears to be associated with younger and larger subsidiaries.

Thus, the results support H1, i.e., there is a relationship between a country's development and the reverse transfer of product innovation. As expected, Brazilian multinationals place subsidiaries in developed countries in an effort to obtain product innovation. This occurs due to Brazil's lack of high technology, a problem common to emerging countries that hinders the development of competitive advantages and, thus, competitive power in the international market.

Product innovation requires high levels of investment in basic science, a highly qualified workforce, partnerships between companies and local universities, high levels of firm investment in $\mathrm{R} \& \mathrm{D}$, and incentives for innovation from government institutions. These are the premises of a developed institutional environment that should lead to a strong innovation system. In addition, product innovation involves high levels of investment with a high degree of uncertainty because one cannot accurately predict the market's acceptance of new products. Together, these factors make the development of product innovation not feasible in markets with unstructured institutional environments, such as Brazil.

Brazilian companies have innovative capabilities, but they are mostly focused on process innovation, which involves less investment and does not necessarily require high technology. However, to compete in a global environment, these companies need to combine the ability to innovate both in processes and in product. Thus, these companies place subsidiaries in developed countries in an effort to obtain advanced technologies. These technologies, together with the companies' existing innovative capabilities, will form their firm-specific assets, which will enable them to compete globally.

Furthermore, under our assumptions, the results show that larger subsidiaries are more likely to engage in the reverse transfer of product innovation. However, contrary to our expectations, it is the newest subsidiaries that most often engage in this type of transfer. One reason for the relationship between subsidiary age and frequency of innovation transfer is the search for knowledge as a strategy for the internationalization of Brazilian companies (Bartlett \& Ghoshal, 2000; Ramamurti, 2008). Once knowledge is acquired, the flow of transfer of innovations from subsidiaries is reduced (Kim, 1997). No relationship between innovation transfer and the mode of entry was found.

Finally, the results cannot support H2, i.e., no relationship was found between the reverse transfer of process innovation and a country's level of development.

\section{Conclusions}

Within the DMNC context, the purpose of this article has been to compare the differences in the flow of innovation transferred from subsidiaries to their headquarters according to the environment in which they are located. More specifically, it was expected that DMNCs' subsidiaries located in developed countries would be more likely to transfer product innovation to their headquarters, whereas subsidiaries located in emerging countries would be more likely to transfer process innovations.

The results support the hypothesis that subsidiaries located in developed countries are more likely to transfer product innovations to their headquarters. However, the results do not support for the hypothesis that subsidiaries located in emerging countries are more likely to transfer innovations in process.

These results confirm the fact that in the process of internationalization, emerging multinational companies, specifically Brazilian companies, allocate their subsidiaries in developed countries for the purpose of obtaining advanced technologies for product development. From this relationship, control variables were identified to examine the profile of these subsidiaries. The data show that the youngest and largest subsidiaries are most likely to transfer this type of innovation. Therefore, the most structured and largest units are the fittest to transfer innovations. The age of these units, however, was an unexpected finding. However, a possible explanation for the transfer occurring in 
younger subsidiaries is precisely the driven factor of the internalization process of these companies. When the primary objective is to access high technology (Bartlett \& Ghoshal, 2000), as knowledge is acquired and absorbed (Kim, 1997) the flow of the reverse transfer of innovation is reduced.

This study, does not find support for an influence by the level of the development of the subsidiary's country on the reverse transfer of process innovation. This leads us to believe that a subsidiary can develop process innovation and transfer it to headquarters in any environment. One explanation for this finding is that when a subsidiary is allocated to an environment different from the one in which it originated, it tends to adapt its counterpart to those already established in this environment (DiMaggio \& Powell, 1983). Thus, business units can access new ways of operating (processes), which may differ from their headquarters' organizational forms; thus, they can develop and transfer innovation processes in both developed and emerging environments.

From an academic perspective, this paper makes some important contributions. According to Lundvall et al. (2002), the literature on IS needs to be better developed and adapted to emerging countries. Additionally, there is a need to understand how innovation transfer occurs in different environments. Thus, this paper has considerable implications for the IS literature, showing the flow of innovation in companies from emerging countries and testing the impact of emerging and developed environments in that process.

Govindarajan and Ramamurti (2011) state that understanding the types of innovation generated in emerging markets based on the literature on IS is an important line of research that needs to be developed. Thus, by merging the two approaches (IS and innovation in emerging markets) to understand the importance of the environment in the innovation process, this paper deepens the international business and innovation literature. Innovation in emerging markets is growing quickly and is greater than ever before (Govindarajan \& Ramamurti, 2011). Therefore, this research contributes to a better understanding of the innovation phenomenon.

The paper also presents implications for policy makers because it confirms the already-established idea that developed IS are conducive to product innovations (Freeman, 1995; Lundvall et al., 2002; Nelson, 1993; Utterback, 1996; Utterback \& Abernathy, 1975). The results also contribute to management practices by introducing a small but important part of the innovation pattern of emerging multinational corporations. Because such companies are increasingly becoming international, with subsidiaries in many types of environments, it is important for managers to understand how differences in environments can contribute to the development of firm-specific assets.

This study's limitations are related primarily to our choice of control variables because just a few factors that influence the process of reverse transfer of innovation have been uncovered. The sample size and the origin of the sampled companies might also be a limiting factor of this research because they can reflect only the specific reality of those particular companies.
One suggestion for future research is the use of multinationals from different sources to verify whether this study's results could be extended to emerging markets worldwide or whether they are particular to Brazil. We also propose a more detailed investigation of the degree of absorption of innovations transferred from subsidiaries to headquarters, both to find what type of innovation is more relevant to the companies and to understand how headquarters are absorbing and learning the technologies transferred from their subsidiaries.

\section{Acknowledgements}

We acknowledge the financial support provided by FAPESP and The Observatório de Multinacionais Brasileiras - ESPM.

\section{References}

Alvaro, C.-C., Rajneesh, N., \& Un, C. A. (2015). Internationalization motives: sell more, buy better, upgrade and escapenull. Multinational Business Review, 23(1), 25-35. doi: 10.1108/MBR-02-2015-0009

Ariffin, N., \& Figueiredo, P. N. (2004). Internationalization of innovative capabilities: counter-evidence from the electronics industry in Malaysia and Brazil. Oxford Development Studies, 32(4), 559-583. doi: $10.1080 / 1360081042000293344$

Bartlett, C. A., \& Ghoshal, S. (2000). Going Global: Lessons from Late Movers. USA: Harvard Business Review.

Bell, M., \& Pavitt, K. (1995). The development of technological capabilities. In I. Ul Haque, M. Bell, C. Dahlman, S. Lall \& K. Pavitt (Eds.), Trade, technology and international competitiveness (pp. 69101). Washington, DC: The World Bank.

Benito, G. R. G., Grogaard, B., \& Narula, R. (2003). Environmental influences on MNE subsidiary roles: economic integration and the Nordic countries. Journal of International Business Studies, 34(5), 443 456. doi: http://dx.doi.org/10.1057/palgrave.jibs.8400047

Cantwell, J., \& Mudambi, R. (2005). MNE competence-creating subsidiary mandates. Strategic Management Journal, 26(12), 1109-1128. doi: $10.1002 /$ smj.497

Cooper, D., \& Schindler, P. (2006). Métodos de Pesquisa em Administração. Porto Alegre: Bookman.

DiMaggio, P. J., \& Powell, W. W. (1983). The Iron Cage Revisited: Institutional Isomorphism and Collective Rationality in Organizational Fields. American Sociological Review, 48(2), 147-160. doi: $10.2307 / 2095101$

Dunning, J. H., \& Lundan, S. M. (2008). Multinational enterprises and the global economy. Cheltenham, U.K: Edward Elgar.

Edquist, C. (2005). Systems of innovation. In J. Fagerberg, D. C. Mowery \& R. R. Nelson (Eds.), The Oxford handbook of innovation (pp. 181-208). New York: Oxford University Press. 
Figueiredo, P. N. (2009). Gestão da inovação: conceitos, métricas e experiências de empresas no Brasil. Rio de Janeiro, RJ: LTC - Livros Técnicos e Científicos Editora S.A.

Fleury, A., Fleury, M. T. L., \& Borini, F. M. (2013). The Brazilian Multinationals' Approaches to Innovation. Journal of International Management, 19(3). doi: http://dx.doi.org/10.1016/j.intman.2013.03.003

Freeman, C. (1995). The 'National System of Innovation' in historical perspective. Cambridge Journal of Economics, 19(1), 5-24.

Govindarajan, V., \& Ramamurti, R. (2011). Reverse innovation, emerging markets, and global strategy. Global Strategy Journal, 1(34), 191-205. doi: 10.1002/gsj.23

Govindarajan, V., \& Trimble, C. (2012). Reverse innovation: a global growth strategy that could pre-empt disruption at home. trategy \& Leadership, 40(5), 5 - 11. doi: 10.1108/10878571211257122

Grossman, G. M., \& Helpman, E. (1991). Trade, knowledge spillovers, and growth. European Economic Review, 35(2-3), 517-526. doi: http:// dx.doi.org/10.1016/0014-2921(91)90153-A

Hair Jr, J. F., Black, W. C., Babin, B. J., Anderson, R. E., \& Tatham, R. L. (2009). Análise Multivariada de Dados (Vol. 6). Porto Alegre: Bookman.

Hobday, M. (2005). Firm-level Innovation Models: Perspectives on Research in Developed and Developing Countries. Technology Analysis \& Strategic Management, 17(2), 121-146. doi: $10.1080 / 09537320500088666$

Iammarino, S., Padilla-Pérez, R., \& von Tunzelmann, N. (2008). Technological capabilities and global-local interactions: The electronics industry in two Mexican regions. World Development, 36(10), 1980-2003.

IMF. (2010). Frequently Asked Questions. Retrieved July 2013 http:// www.imf.org/external/pubs/ft/weo/faq.htm

Immelt, J. R., Govindarajan, V., \& Trimble, C. (2009). How GE is disrupting itself. Harvard Business Review, October, 56-65.

Johnston, S., \& Menguc, B. (2007). Subsidiary size and the level of subsidiary autonomy in multinational corporations: a quadratic model investigation of Australian subsidiaries. Journal of International Business Studies, 38(5), 787-801. doi: http://dx.doi.org/10.1057/ palgrave.jibs.8400294

Kim, L. (1997). Imitation to innovation: The dynamics of Korea's technological learning. Cambridge, MA: Harvard Business School Press.

Kottaridi, C., Papanastassiou, M., Pitelis, C. N., \& Thomakos, D. D. (2008). The Multinational Corporation and the Global Sourcing of Knowledge: Remodeling Absorptive Capacity. Economic and Social Research Institute (ESRI).

Lundvall, B.-Å., Johnson, B., Andersen, E. S., \& Dalum, B. (2002).
National systems of production, innovation and competence building. Research Policy, 31(2), 213-231. doi: http://dx.doi.org/10.1016/ S0048-7333(01)00137-8

Maroco, J. (2010). Análise Estatística com o PASW Statistics (ex-SPSS). Portugal, Lisboa: Editora ReportNumber.

Meyer, K. E., Estrin, S., Bhaumik, S. K., \& Peng, M. W. (2009). Institutions, resources, and entry strategies in emerging economies. Strategic Management Journal, 30(1), 61-80. doi: 10.1002/smj.720

Mudambi, R., Piscitello, L., \& Rabbiosi, L. (2014). Reverse Knowledge Transfer in MNEs: Subsidiary Innovativeness and Entry Modes. Long Range Planning, 47(1-2), 49-63. doi: 10.1016/j.lrp.2013.08.013

Nelson, R. R. (1993). National Innovation Systems: A comparative analysis. New York: Oxford University Press.

Nelson, R. R. (2006). Sistemas Nacionais de Inovação: retrospecto de um estudo. In R. Nelson (Ed.), As Fontes do Crescimento Econômico (Vol. Clássicos da Inovação, pp. 427- 467). Campinas: Unicamp.

OECD. (1997). Oslo Manual: The measurement of scientific and technological activities - Proposed guidelines for collecting and interpreting technological innovation data (pp. 35-54).

Prahalad, C. K., \& Hart, S. L. (2002). The fortune at the bottom of the pyramid. Strategy+Business, 26(1st quarter), 2-14.

Prahalad, C. K., \& Mashelkar, R. A. (2010). Innovation's Holy Grail. Harvard Business Review, 88(7/8), 132-141.

Ramamurti, R. (2008). What Have We Learned About Emerging-Market MNEs? Insights from a Multi-Country Research Project. Paper presented at the Emerging Multinationals: Outward FDI from Emerging and Developing Economies, Copenhagen, Denmark.

Schumpeter, J. A. (1928). The Instability of Capitalism. The Economic Journal, 38(151), 361-386. doi: 10.2307/2224315

Utterback, J. M. (1996). Dynamics of innovation USA: Harvard Business School Press.

Utterback, J. M., \& Abernathy, W. J. (1975). A dynamic model of process and product innovation. Omega, 3(6), 639-656. doi: http:// dx.doi.org/10.1016/0305-0483(75)90068-7

Verbeke, A., \& Kano, L. (2015). The New Internalization Theory and Multinational Enterprises from Emerging Economies: A Business History Perspective. Business History Review, 89(03), 415-445. doi: doi:10.1017/S0007680515000689

Vernon-Wortzel, H., \& Wortzel, L. H. (1988). Globalizing strategies for multinationals from developing countries. Columbia Journal of World Business, 23(1), 27-36.

Wright, B., \& Schwager, P. H. (2008). Online Survey Research: Can Response Factors Be Improved? Journal of Internet Commerce, 7(2), 253-269. doi: 10.1080/15332860802067730 